\title{
Human T Cell Lymphotrophic Virus 1/2 in Solid Organ Transplantation
}

\section{R. Kaul ${ }^{a, *}$, J. A. Davis ${ }^{b}$ and the AST Infectious Diseases Community of Practice}

a Department of Internal Medicine, Division of Infectious Diseases, University of Michigan Medical School, Ann Arbor, MI

${ }^{\mathrm{b}}$ Department of Internal Medicine, Division of Infectious Diseases, Ohio State University College of Medicine, Columbus, $\mathrm{OH}$

*Corresponding author: Daniel R. Kaul, kauld@umich.edu

Key words: donor-to-host transmission, human $\mathrm{T}$ lymphotrophic virus, leukemia, screening

\begin{abstract}
Abbreviations: ATL, adult T cell leukemia/lymphoma; EIA, enzyme linked immunosorbent assays; FDA, Food and Drug Administration; HAM/TSP, human T cell lymphotrophic virus associated myelopathy/tropical spastic paraparesis; HTLV, human $T$ cell lymphotrophic virus; NHL, Non-Hodgkins lymphoma; PBMC, peripheral blood mononuclear cells; PCR, polymerase chain reaction; PTLD, posttransplant lymphoproliferative disease; SOT, solid organ transplantation; US, United States.
\end{abstract}

\section{Epidemiology and Risk Factors}

\section{General epidemiology}

Human T cell lymphotrophic virus 1 (HTLV)- 1 is a delta retrovirus endemic in the Caribbean, parts of South America (highest rates reported in Brazil, Peru, Ecuador and Venezuela), West Africa, Asia (particularly Southwestern Japan) and Oceania. In areas of highest endemicity, 2-6\% of adults are infected $(1,2)$. Infection is much less common in North America. For example, in the United States (US) $0.035-0.046 \%$ of blood donors are infected with HTLV-1 or HTLV-2 (3). Among potential organ donors in France and the United States, similarly low rates of HTLV-1 $(0.03-$ $0.067 \%$ ) have been reported (4,5). In endemic areas, breastfeeding is the predominant mode of transmission (2). HTLV-1 may also be transmitted via intravenous drug use, sexual intercourse (inefficiently), solid organ transplantation (SOT) and transfusion of cell-containing blood products (14.4-47.3\% of recipients) $(6,7)$. HTLV-2, in contrast, is primarily found in intravenous drug users and sexual contacts of infected persons and is endemic in some indigenous populations of North, Central and South America and in West and Central Africa.
HTLV-1 establishes latent infection in lymphocytes and infection persists for life. While most patients remain asymptomatic, following a prolonged period of latency $2-5 \%$ of infected patients develop adult T cell leukemia/lymphoma (ATL). In Southwestern Japan, 75\% of non-Hodgkins lymphoma (NHL) is ATL (7). In addition to ATL, a small percentage of infected individuals develop severe neurological disease termed HTLV-1 associated myelopathy/tropical spastic paraparesis (HAM/TSP). Other inflammatory disorders and less severe neurological disease have also been associated with HTLV-1 and no reliably effective treatment is available. Unlike HTLV-1, the link between HTLV-2 and human disease is uncertain, although there have been occasional case reports of neurological disease, inflammatory disorders, and leukemia in infected patients (8). Thus at present, for the purpose of organ donation, HTLV-2 is not considered a human pathogen and organs from HTLV-2 positive donors are generally not considered to present an increased risk of donor-derived disease compared to organs from HTLV-2 negative donors. This guideline will focus on HTLV-1 infection.

\section{Recipients positive pretransplantation}

The effect of immunosuppression on the natural history of HTLV-1 is not well defined as very few cases have been described. This is an important issue in determining the safety of organ transplantation in HTLV-1 positive recipients. Case series from Japan describe 35 HTLV-1 positive kidney recipients with long-term follow up; no HTLV-1 disease occurred (9-11). In contrast, a series of patients with posttransplant lymphoproliferative disease (PTLD) describes the development of HTLV-1 associated ATL in five renal transplant recipients (unknown if all cases were infected pre-transplant) with death occurring in four or five patients (12). Among 26 HTLV-1 positive living donor liver recipients, four (15\%) developed ATL with fatal outcomes in all cases (13). Overall survival, however, did not differ between HTLV-1 positive and negative recipients.

\section{Donor derived HTLV-1 infection}

Since 1999, 162 HTLV 1/2 screen positive organs have been transplanted in the United States with no HTLV-1 associated disease described in recipients $(5,14,15)$. In virtually all cases, however, confirmatory tests were not performed on donors and analysis based on the performance of the HTLV-1/2 screening assay in a low seroprevalence population indicates that most of these donors had HTLV-2 or a false positive screening assay (5). Further, the OPTN 
database tracks malignancy but not neurological outcome. Thus, the absence of reports of HTLV-1 associated disease in this population does not indicate that true positive HTLV1 organs can be safely transplanted.

Only a few case reports describe proven HTLV-1 transmission from seropositive donor to seronegative recipient (16-19). The most convincing case of donor-derived disease occurred in Spain in which three seronegative recipients of an HTLV-1 seropositive donor developed myelopathy within 2 years of transplantation (17). A heart transplant who received HTLV-1 infected blood at the time of transplantation developed severe HAM 18 weeks after transplantation (20). A number of other reports describe donor to recipient HTLV-1 transmission without known development of disease $(13,16,18,19)$.

Recommendation: While the impact of immunosuppression on the natural history of HTLV-1 is not fully understood, persons seropositive for HTLV-1 can be considered for transplantation. Given that these recipients may face a higher (but difficult to quantify) risk of serious disease (ATL and HAM/TSP), information regarding this risk should be provided to HTLV-1 positive potential recipients as part of the informed consent process (Category II-2).

\section{Diagnosis}

\section{Laboratory diagnosis of HTLV-1}

Enzyme linked immunosorbent assays (EIA) are currently used as screening tests for HTLV-1/2. These tests do not distinguish between HTLV-1 and HTLV-2. Further, diagnosis of HTLV-1 infection is a two-step process requiring a confirmatory assay. The most commonly used confirmatory assays include Western blot and line immunoassays. Depending on the assay design and the results in a particular patient, these confirmatory immunoassays may distinguish between HTLV-1 and HTLV-2. Polymerase chain reaction (PCR) tests may also be useful to confirm infection (particularly in the case of an indeterminate confirmatory test) and can distinguish between infection with HTLV-1 and HTLV-2. As plasma viremia is not prominent in HTLV1 infection, PCR tests are best performed on peripheral blood mononuclear cells (PBMCs). In some studies, however, PCR is less sensitive than serological methods for the diagnosis of HTLV-1/2, and may be even lower for HTLV-2 (21). No confirmatory tests or nucleic acid based tests are currently approved by the FDA, and in most settings confirmatory results are not available in a time frame adequate to make decisions regarding deceased donor organ donation.

Screening EIA tests are highly sensitive but have poor positive predictive value when applied to a low seroprevalence population. For example, using the Abbott HTLV I/II EIA assay (now discontinued) 15215 blood donors, 51 (0.35\%) were repeatedly reactive; only 10 of these had positive confirmatory tests and only 4 had confirmed HTLV-1. Thus, only $4 / 51(7.9 \%)$ of screen positive patients had confirmed
HTLV-1 infection (22). In patients with medical conditions unrelated to HTLV-1/2, higher rates of positive screens are obtained (26/639), but only $3 / 26$ were confirmed to have HTLV-1 infection (22). Likewise, among potential organ donors, HTLV-1 infection could not be confirmed in the majority of screen positive donors (5).

Recommendations: Whenever possible, HTLV-1/2 screen positive results should be confirmed with Western blot, line immunoassay, or polymerase chain reaction (Category II-1).

\section{Treatment}

Currently no proven medical treatment for asymptomatic carriers of HTLV-1 exists. Antiretrovirals effective in HIV infection have achieved mixed results at best in reducing HTLV proviral loads (the typically stable amount of virus present in infected cells) (23-27) and this is unsurprising as viral replication is sustained by cellular division rather than highly active viral production (24). Other proposed treatments for asymptomatic carriers or patients with HAM/TSP include corticosteroids, alpha interferon, anti-CD25 monoclonal antibody, cyclosporine and valproic acid which increases viral expression theoretically leading to enhanced immune surveillance (24). Overall, treatment is focused on management of sequelae of HTLV1 infection-namely ATL and HAM/TSP-in carriers who develop HTLV-1 associated disease.

Recommendations: No specific proven treatment for asymptomatic HTLV-1 infection is currently available.

\section{Prevention}

\section{Donor screening}

As a result of both the impending discontinuation of the Abbott HTLV I/II assay in 2009 and concern regarding the high false positive rate of available assays, an analysis of universal HTLV-1 screening in deceased donors was undertaken. This suggested that 167-227 uninfected organs were discarded yearly due to false positive screening tests (5). A separate analysis estimated that in a low prevalence population the ratio of false positive to true positive HTLV-1 screening assays was 40:1 (28). Based on these considerations, the requirement for HTLV-1 screening of deceased donors was removed by OPTN/UNOS in 2009.

In general, OPTN/UNOS policy limits recommendations for laboratory testing to assays approved by the FDA for purpose of donor screening. Currently, three assays are FDA approved for screening in the United States (29). The characteristics of each assay are described in Table 1. A major limitation to donor screening is the inability of any licensed screening test to distinguish HTLV-1 from HTLV-2 and the 
Human T Cell Lymphotrophic Virus $1 / 2$ in Solid Organ Transplantation

Table 1: FDA approved HTLV-1/2 screening assays

\begin{tabular}{ll}
\hline Assay & \multicolumn{1}{c}{ Comments } \\
\hline Abbott HTLV-I/II & Practical for OPO use \\
& No longer available in the United States \\
& Does not distinguish between HTLV-1 and \\
& HTLV-2 \\
Designed for large scale use (blood produce & donor screening) \\
Abbott prism & Not practical in most OPO laboratories \\
HTLV-I/II & Requires significant investment in \\
& expensive equipment and reagents \\
& Does not distinguish between HTLV-1 and \\
& HTLV-2 \\
Avioq HTLV-I/II & Approved for HTLV screening \\
microelisa & Recently approved (March 2012) and \\
system & practicality for OPO use unproven \\
& Does not distinguish between HTLV-1 and \\
HTLV-2
\end{tabular}

lack of a confirmatory test that can be completed prior to organ donation.

\section{Follow up of recipients at risk for donor-derived HTLV-1}

The optimal management and follow up of recipients receiving organs from donors proven or suspected to have HTLV-1 is unknown. In cases of screen positive donors, every effort should be made to perform confirmatory tests on stored donor samples to determine if the donor is actually HTLV-1 infected. Recipients of HTLV-2 positive donors or those with negative confirmatory assays do not require specific follow-up. If the donor is proven to have HTLV-1 or confirmatory tests cannot be done or are indeterminate, periodic testing for HTLV-1 using both serological (may have low sensitivity in immunosuppressed patients) and nucleic acid based testing on the recipient is indicated. Testing quarterly for 1 year and then biannually for 1 year would be a reasonable approach. While therapeutic options are uncertain, recipients would benefit from knowing their HTLV-1 status to prevent secondary (sexual or breastfeeding) transmission (see later). Further, HTLV-1 viral loads are higher in patients with neurological disease than in asymptomatic carriers $(30,31)$ and patients with donor-derived infection might benefit from viral load guided modulation in their immunosuppression. While HTLV-1 viral loads appear to be maintained by cell division rather than production of new virus and tend to remain stable, this may not be true in immunosuppressed patients.

Standardized clinical monitoring for complications of HTLV-1 infection is not well established. ATL may present with any of a number of clinical features, including generalized adenopathy, cutaneous lesions, hypercalcemia, bony lesions and/or isolated peripheral blood abnormalities/leukemia. HAM/TSP is equally variable in clinical manifestation, and may present with stiff gait, spasticity and lower extremity weakness, back pain, urinary incontinence, impotence, paresthesias, decreased sensation (particularly for posterior column modalities such as vibratory sense) and upper motor neuron signs (32) .

\section{Risk to Staff}

HTLV-1 is spread by cell-associated virus, rather than by cell-free virus and body fluids, and is transmitted by blood products, sexual activity and breastfeeding. As with other blood borne pathogens, the greatest risk for healthcare workers caring for an HTLV-1 infected patient is accidental inoculation via contaminated sharps. While transmission of both HTLV-1 and HTLV-2 in the occupational setting have been reported $(33,34)$, in another report no seroconversions occurred among 34 healthcare workers exposed by puncture wounds (35). No data exist on appropriate prophylaxis for individuals exposed to HTLV. While some have recommended the use of antiretroviral agents in settings of severe exposure (e.g. zidovudine/lamivudine/raltegravir; Refs. $(27,36,37)$, the CDC and other US agencies do not recommend postexposure prophylaxis due to the lack of available data. As with other blood borne pathogens, universal, standard precautions and scrupulous sharps safety are considered sufficient for the prevention of HTLV acquisition.

\section{Risk to others (secondary transmission)}

In the nonoccupational setting, transmission may occur horizontally (usually through sexual activity, or through sharing of injection drug needles) or vertically (mother-to-child, almost entirely through breastfeeding). These can be issues for a recipient who received an HTLV-1 infected or possibly infected organ, or for an HTLV-uninfected SOT recipient who may be entering a sexual relationship with an HTLV-infected partner. The effects of immunosuppression on the risk of acquisition of HTLV are not understood, though at least one animal model suggests that cyclosporine at the time of HTLV-1 infection increased the viral set point and might result in increased risk of the development of HTLV-1 associated disease (38). For the HTLV-1 infected SOT recipient, a few general comments apply with respect to transmission. Sexual transmission of HTLV-1 can be prevented effectively with condom use and other safer sex practices (as recommended for prevention of HIV transmission). Transmission by (injection) needles can be minimized by employment of sterile needles with each use, and by avoidance of sharing of needles and other potentially contaminated equipment. Vertical transmission can be decreased by avoidance of breastfeeding (particularly in the United States and other resource-rich settings, where breast milk alternatives are available).

\section{Recommendations: (Table 2)}

(1) In low seroprevalence areas (like North America), only in extreme circumstances should confirmed HTLV-1 
Kaul et al.

Table 2: Summary of recommendations

\begin{tabular}{|c|c|c|c|}
\hline \multicolumn{2}{|c|}{ Recommendation } & \multirow{2}{*}{$\begin{array}{c}\begin{array}{c}\text { Level of } \\
\text { evidence }\end{array} \\
11-2\end{array}$} & Comment \\
\hline Epidemiology & $\begin{array}{l}\text { HTLV-1 seropositive individuals should not } \\
\text { be excluded from transplantation, but } \\
\text { informed consent should be obtained. }\end{array}$ & & $\begin{array}{l}\text { Reports demonstrate good outcomes without the } \\
\text { development of HTLV-1 disease after } \\
\text { transplantation. } \\
\text { Immunosuppression may speed the development of } \\
\text { HTLV-1 disease; HTLV-1 related deaths have been } \\
\text { reported after organ transplantation. }\end{array}$ \\
\hline Diagnosis & $\begin{array}{l}\text { Whenever possible, screen positive results } \\
\text { should be confirmed with Western blot, } \\
\text { line immunoassay, or PCR. }\end{array}$ & III & $\begin{array}{l}\text { Most screen positive donors or recipients will not } \\
\text { have HTLV-1. }\end{array}$ \\
\hline Treatment & $\begin{array}{l}\text { No specific proven treatment of } \\
\text { asymptomatic HTLV-1 infection is } \\
\text { available. }\end{array}$ & III & $\begin{array}{l}\text { Proposed treatments include corticosteroids, alpha } \\
\text { interferon, anti-CD25 monoclonal antibody, } \\
\text { cyclosporine and valproic acid. }\end{array}$ \\
\hline Prevention & $\begin{array}{l}\text { In low seroprevalence areas, confirmed } \\
\text { HTLV-1 positive donors should only be } \\
\text { used in extreme circumstances. }\end{array}$ & $\| 1-3$ & $\begin{array}{l}\text { While routine screening is no longer required, in some } \\
\text { circumstances (e.g. living donors) confirmed } \\
\text { serostatus may be available. }\end{array}$ \\
\hline \multirow[t]{3}{*}{$\begin{array}{l}\text { Donor } \\
\quad \text { screening }\end{array}$} & $\begin{array}{l}\text { Routine screening of all deceased donors } \\
\text { for HTLV-1 is not recommended. }\end{array}$ & III & $\begin{array}{l}\text { In low seroprevalence areas, most screen positive } \\
\text { donors do not have HTLV-1 resulting in significant } \\
\text { wastage of uninfected organs. }\end{array}$ \\
\hline & $\begin{array}{l}\text { Individual OPO's with higher prevalence } \\
\text { populations (e.g. immigrants from high } \\
\text { prevalence countries) could consider } \\
\text { targeted screening. }\end{array}$ & III & $\begin{array}{l}\text { While a positive screening test in a higher risk donor } \\
\text { is more likely to represent a true positive, even in } \\
\text { this circumstance if a timely confirmatory test } \\
\text { cannot be performed most screen positive donors } \\
\text { will likely not have HTLV-1. }\end{array}$ \\
\hline & $\begin{array}{l}\text { Living donors with epidemiological risk } \\
\text { factors (e.g. previous residence in } \\
\text { endemic area) should be screened as } \\
\text { time frame allows for performance of } \\
\text { confirmatory testing. }\end{array}$ & III & $\begin{array}{l}\text { Reports of donor derived HTLV-1 disease justify } \\
\text { testing in higher epidemiological risk donors when } \\
\text { adequate time for confirmatory testing is available. }\end{array}$ \\
\hline \multirow[t]{4}{*}{$\begin{array}{l}\text { Recipient } \\
\text { issues }\end{array}$} & $\begin{array}{l}\text { Periodic testing (quarterly for } 1 \text { year and } \\
\text { then biannually for } 1 \text { year) with both PCR } \\
\text { and serology should be performed on } \\
\text { recipients of proven or suspected HTLV-1 } \\
\text { infected donors. }\end{array}$ & III & $\begin{array}{l}\text { While no proven intervention is available, recipients } \\
\text { with the potential for donor-derived HTLV-1 should } \\
\text { be made aware of the risk of secondary } \\
\text { transmission (sexual or breastfeeding) and } \\
\text { investigational treatments/prophylaxis could be } \\
\text { considered. }\end{array}$ \\
\hline & $\begin{array}{l}\text { Follow up of HTLV-1 positive SOT recipients } \\
\text { should include regular clinical monitoring } \\
\text { for complications of infection, including } \\
\text { ATL and HAM/TSP. }\end{array}$ & III & $\begin{array}{l}\text { Investigational (HAM/TSP) and standard (ATL) } \\
\text { treatments could be considered. }\end{array}$ \\
\hline & $\begin{array}{l}\text { SOT recipients who are HTLV-1 infected (or } \\
\text { received potentially infected organs) } \\
\text { should be counseled about risks of } \\
\text { transmission to others, including how to } \\
\text { minimize those risks. }\end{array}$ & III & $\begin{array}{l}\text { HTLV-1 can be transmitted through sexual contact, } \\
\text { breastfeeding, or sharing injection needles. HTLV-1 } \\
\text { cannot be transmitted through casual contact. }\end{array}$ \\
\hline & $\begin{array}{l}\text { SOT recipients who are at risk for acquiring } \\
\text { HTLV-1 should be counseled on modes of } \\
\text { transmission and how to minimize the } \\
\text { risk of acquisition. In general, these } \\
\text { recommendations follow those for other } \\
\text { viruses such at HIV or hepatitis C } \\
\text { (Category III). }\end{array}$ & III & $\begin{array}{l}\text { This would primarily apply to transplant recipients who } \\
\text { are sexual partners of HTLV-1 infected individuals. }\end{array}$ \\
\hline \multirow[t]{2}{*}{$\begin{array}{l}\text { Infection } \\
\text { control }\end{array}$} & $\begin{array}{l}\text { Standard, universal precautions should be } \\
\text { employed when providing care to } \\
\text { patients with HTLV infection. }\end{array}$ & III & $\begin{array}{l}\text { In occupational settings, HTLV-1 transmission is } \\
\text { similar to other blood borne viruses (HIV). }\end{array}$ \\
\hline & $\begin{array}{l}\text { There is insufficient evidence to } \\
\text { recommend occupational postexposure } \\
\text { prophylaxis for those who are exposed to } \\
\text { HTLV-1. }\end{array}$ & III & $\begin{array}{l}\text { The use of antiretrovirals immediately after exposure } \\
\text { could theoretically prevent the establishment of } \\
\text { infection, but there are only in vitro data to support } \\
\text { this. }\end{array}$ \\
\hline
\end{tabular}

$\overline{\mathrm{ATL}}=$ adult T cell leukemia; HAM/TSP = HTLV-associated myelopathy/tropical spastic paraparesis; HIV = human immunodeficiency virus; $\mathrm{HTLV}=$ human $\mathrm{T}$ cell lymphotrophic virus; OPO = organ procurement organizations; $\mathrm{PCR}=$ polymerase chain reaction; SOT = solid organ transplant. 
seropositive donors be used. As routine HTLV-1 screening of deceased donors is no longer performed by most OPOs, the most likely scenario would be a living donor in whom confirmatory testing could be performed or a high risk deceased donor in whom screening and confirmatory testing is performed (Category II-3).

(2) Due to the low seroprevalence of HTLV-1 in the United States and the poor positive predictive value of screening HTLV-1/2 assays in this population, routine screening of all deceased donors is not recommended (Category II-3).

(3) Individual OPOs with higher prevalence populations (e.g. a high proportion of immigrants from endemic countries) could consider targeted or universal screening. However, even in these higher risk donors, most screen positive donors likely will not have HTLV-I (Category III).

(4) Living donors with epidemiological risk factors for HTLV-1 should be screened for HTLV-1 as in this situation adequate time to perform confirmatory testing is available (Category III).

(5) Recipients of confirmed or suspected HTLV-1 infected organs should undergo periodic monitoring using both serological and nucleic acid based testing (quarterly for 1 year then every 6 months for 1 year) (Category III).

(6) Follow up of HTLV-positive SOT recipients should include regular clinical monitoring for complications of infection, including ATL and HAM/TSP (focusing on the skin, lymph nodes, hematologic system and neurologic system) (Category III).

(7) SOT recipients who are HTLV-infected (or received potentially infected organs) should be counseled about risks of transmission to others, including how to minimize those risks (Category III).

(8) SOT recipients who are at risk for acquiring HTLV1 should be counseled on modes of transmission and how to minimize the risk of acquisition. In general, these recommendations follow those for other viruses such at HIV or hepatitis C (Category III).

(9) Standard, universal precautions should be employed when providing care to patients with HTLV-1 infection (Category III).

(10) There is insufficient evidence to recommend occupational postexposure prophylaxis for those who are exposed to HTLV-1 (Category III).

\section{Future Research}

A number of important issues regarding HTLV-1/2 and SOT recipients remain undefined. Perhaps most importantly, given the recent elimination of the requirement for deceased donor HTLV-1/2 screening, the transplant community should monitor for cases of ATL or HAM in recipients that could represent donor derived infection. If significant numbers of cases are noted, targeted donor screening or universal screening using improved assays could be considered. We also need to better understand the effect of immunosuppression on the natural history of asymptomatic HTLV-1 infection, and additional case series from endemic regions are needed. Finally, further studies are needed to better define the role of antiretrovirals as postexposure prophylaxis.

\section{Disclosure}

The authors of this manuscript have no conflicts of interest to disclose as described by the American Journal of Transplantation.

\section{References}

1. Blattner WA, Saxinger C, Riedel D, et al. A study of HTLV-I and its associated risk factors in Trinidad and Tobago. J Acquir Immune Defic Syndr 1990; 3: 1102-1108.

2. Proietti FA, Carneiro-Proietti AB, Catalan-Soares BC, Murphy EL. Global epidemiology of HTLV-I infection and associated diseases. Oncogene 2005; 24: 6058-6068.

3. Glynn SA, Kleinman SH, Schreiber GB, et al. Trends in incidence and prevalence of major transfusion-transmissible viral infections in US blood donors, 1991 to 1996. Retrovirus Epidemiology Donor Study (REDS). JAMA 2000; 284: 229-235.

4. Claquin J, Romano P, Noury D, et al. Human T lymphotropic virus $1-2$ positive antibodies in potential organ donors in France. Transplant Proc 1996; 28: 189-190.

5. Kaul DR, Taranto S, Alexander C, et al. Donor screening for human T-cell lymphotrophic virus 1/2: Changing paradigms for changing testing capacity. Am J Transplant 2010; 10: 207-213.

6. Manns A, Wilks RJ, Murphy EL, et al. A prospective study of transmission by transfusion of HTLV-I and risk factors associated with seroconversion. Int J Cancer 1992; 51: 886-891.

7. Martin-Davila P, Fortun J, Lopez-Velez R, et al. Transmission of tropical and geographically restricted infections during solid-organ transplantation. Clin Microbiol Rev 2008; 21: 60-96.

8. Murphy E, Roucoux D. The epidemiology and disease outcomes of human T-lymphotropic virus type II. AIDS Rev 2004; 6: 144-154.

9. Nakamura N, Tamaru S, Ohshima K, Tanaka M, Arakaki Y, Miyauchi T. Prognosis of HTLV-I-positive renal transplant recipients. Transplant Proc 2005; 37: 1779-1782.

10. Tanabe K, Kitani R, Takahashi K, et al. Long-term results in human T-cell leukemia virus type 1-positive renal transplant recipients. Transplant Proc 1998; 30: 3168-3170.

11. Shirai H, Suzuki M, Tomita Y, et al. Renal transplantation in patients with human T-cell lymphotropic virus type 1. Transplant Proc 2012; 44: 83-86.

12. Hoshida Y, Li T, Dong Z, et al. Lymphoproliferative disorders in renal transplant patients in Japan. Intl J Cancer 2001; 91: 869875.

13. Yoshizumi T, Shirabe K, Ikegami T, et al. Impact of human T cell leukemia virus type 1 in living donor liver transplantation. Am J Transplant 2012; 12: 1479-1485.

14. Marvin MR, Brock GN, Kwarteng K, et al. Increasing utilization of human T-cell lymphotropic virus $(+)$ donors in liver transplantation: Is it safe? Transplantation 2009; 87: 1180-1190. 


\section{Kaul et al.}

15. Shames BD, D'Alessandro AM, Sollinger HW. Human T-cell lymphotrophic virus infection in organ donors: A need to reassess policy? Am J Transplant 2002; 2: 658-663.

16. Remesar MC, del Pozo AE, Pittis MG, Mangano AM, Sen L, Briones L. Transmission of HTLV-I by kidney transplant. Transfusion 2000; 40: 1421-1422.

17. Toro $C$, Benito $R$, Aguilera $A$, et al. Infection with human $T$ lymphotropic virus type I in organ transplant donors and recipients in Spain. J Med Virol 2005; 76: 268-270.

18. Yara S, Fujita J, Date H. Transmission of human T-lymphotropic virus type I by bilateral living-donor lobar lung transplantation. J Thorac Cardiovasc Surg 2009; 138: 255-256.

19. Nakamura N, Arakaki Y, Sunagawa H, et al. Influence of immunosuppression in HTLV-1-positive renal transplant recipients. Transplant Proc 1998; 30: 1324-1326.

20. Gout O, Baulac M, Gessain A, et al. Rapid development of myelopathy after HTLV-I infection acquired by transfusion during cardiac transplantation. N Engl J Med 1990; 322: 383-388.

21. Lee TH, Chafets DM, Busch MP, Murphy EL. Quantitation of HTLVI and II proviral load using real-time quantitative PCR with SYBR Green chemistry. J Clin Virol 2004; 31: 275-282.

22. Package Insert: Abbott HTLV-I/HTLV-II EIA.

23. Gout $O$, Gessain A, Iba-Zizen M, et al. The effect of zidovudine on chronic myelopathy associated with HTLV-1. J Neurol 1991; 238: 108-109.

24. Martin F, Taylor GP. Prospects for the management of human Tcell lymphotropic virus type 1-associated myelopathy. AIDS Rev 2011; 13: 161-170.

25. Sheremata WA, Benedict D, Squilacote DC, Sazant A, DeFreitas E. High-dose zidovudine induction in HTLV-I-associated myelopathy: Safety and possible efficacy. Neurology 1993; 43: 21252129.

26. Taylor GP, Goon P, Furukawa Y, Green H, Barfield A, Mosley A, et al. Zidovudine plus lamivudine in human T-lymphotropic virus typeI-associated myelopathy: A randomised trial. Retrovirology 2006; 3: 63-71

27. Treviño A, Parra P, Bar-Magen T, Garrido C, de Mendoza C, Soriano V. Antiviral effect of raltegravir on HTLV-1 carriers. J Antimicrobial Chemother 2012; 67: 218-221.
28. Huang RC, Fishman JA. Screening of deceased organ donors: No easy answers. Transplantation 2011; 91: 146-149.

29. Food and Drug Administration. 2012; Available at: www.fda.gov/ BiologicsBloodVaccines/BloodBloodProducts/ApprovedProducts/ licensedProductsBLAs/BloodDonorScreening/InfectiousDisease/ ucm090707.htm. Accessed May 15, 2012.

30. Grassi MFR, Olavarria VN, Kruschewsky RdA, et al. Human T cell lymphotropic virus type 1 (HTLV-1) proviral load of HTLV-associated myelopathy/tropical spastic paraparesis (HAM/TSP) patients according to new diagnostic criteria of HAM/TSP. J Med Virol 2011; 83: $1269-1274$.

31. Silva MT, Harab RC, Leite AC, Schor D, Araujo A, Andrada-Serpa MJ. Human T lymphotropic virus type 1 (HTLV-1) proviral load in asymptomatic carriers, HTLV-1-associated myelopathy/tropical spastic paraparesis, and other neurological abnormalities associated with HTLV-1 infection. Clin Infect Dis 2007; 44: 689692.

32. Goncalves DU, Proietti FA, Ribas JG, et al. Epidemiology, treatment, and prevention of human T-cell leukemia virus type 1-associated diseases. Clin Microbiol Rev 2010; 23: 577589.

33. Kataoka R, Takehara N, Iwahara Y, et al. Transmission of HTLV-I by blood transfusion and its prevention by passive immunization in rabbits. Blood 1990; 76: 1657-1661.

34. Menna-Barreto M. HTLV-II transmission to a health care worker. Am J Infect Control 2006; 34: 158-160.

35. Amin RM, Jones $B$, Rubert $M$, et al. Risk of retroviral infection among retrovirology laboratory and health care workers. American Society for Microbiology 92nd General Meeting, New Orleans, Louisiana, May 26-30, 1992. (abstract T-20).

36. Electronic Therapeutic Guidelines. Available at: http://www.tg.org. au/etg_demo/tgc/abg/4651.htm\#4703ID_GL. Accessed May 15, 2012.

37. Seegulam ME, Ratner L. Integrase inhibitors effective against human T-cell leukemia virus type 1. Antimicrob Agents Chemother 2011; 55: 2011-2017.

38. Haynes RA, 2nd, Ware E, Premanandan C, et al. Cyclosporineinduced immune suppression alters establishment of HTLV-1 infection in a rabbit model. Blood 2010; 115: 815-823. 